\title{
EXPANDING THE BODY OF KNOWLEDGE CONCEPT for Professional Practitioners
}

\author{
Witold Kinsner \\ Cognitive Systems Laboratory \\ Department of Electrical and Computer Engineering \\ University of Manitoba, Winnipeg, MB, Canada R3T 5V6 \\ witold.kinsner@umanitoba.ca
}

\begin{abstract}
In recent years, the emergence of many new disciplines and the increasing depth of existing disciplines have prompted the development of the Body of Knowledge (BoK) concept in order to improve the uniformity of new undergraduate programs in accredited professional schools, and to provide a requisite standard for certifications in vocational education. A body of knowledge is the collected wisdom, experience, processes, and facts that both inform a profession and provide the solid foundation from which continuous improvements and innovative change can occur. This paper provides arguably the first summary of $32 \mathrm{BoK}$ examples, and proposes a new model of a BoK for professional practitioners
\end{abstract}

Keywords: Body of Knowledge (BoK); BoK for practitioners (BoK4P); continuing education; life-long learning; professional practitioners.

\section{INTRODUCTION}

\subsection{Body of Knowledge}

In the last two decades, the emergence of many new disciplines and the extended depth of existing disciplines have prompted the development of the body of knowledge (BoK) concept in order to improve the uniformity of new undergraduate programs in accredited professional schools. A body of knowledge is the collected wisdom, experience, processes, and facts that both inform a profession and provide the solid foundation from which continuous improvements and innovative change can occur.

There are many definitions of body of knowledge, from the objective and general to very narrow. Wikipedia defines it as the complete set of concepts, terms, and activities that make up a professional domain, as defined by the relevant professional association. From the educational perspective, it is the prescribed aggregation of knowledge in a specific area that a student is expected to have mastered to be considered or certified as a practitioner. From a business perspective, it is the domain of essential information whose mastery is required for success in a field or profession. Thus, a BoK is the ontology for a specific discipline. The BoK also means the document containing the above collections of knowledge. The early BoK examples include Computer Engineering [37] and Software Engineering [10]. The results of a study of 32 such examples are summarized in this paper.

\subsection{Body of Knowledge}

Based on our study, a body of knowledge has distinct attributes such as (i) it provides specific information about the discipline of interest and its best practices; (ii) it provides a taxonomy of the fundamental topics of the discipline; (iii) it promotes application of principles to new problems, systems thinking, creativity, and discovery of new opportunities; (iv) it is intended to prepare students for the uncertainties of the future and appropriate approaches to managing uncertainties due to emerging technologies, increasing complexity of systems, the need for sustainability, globalization, and interdisciplinary approach to system design and development; (v) it is intended to develop awareness of life-long learning; (vi) it is compiled by a multitude of reliable and credible sources, (vii) is not cast in stone, but evolving through discussions about its validity and currency, (viii) it is intended to improve either an educational or a training program, or/and the actual individuals and organizations who participate in the programs, or provide a preparation frameworks for a certification or a licensure.

\subsection{New Vision of Body of Knowledge}

In the past, many educational institutions spent much effort on the delivery of education through technology. Another direction was to use technology to develop education tailored to an individual student, such as the Keller's Personalized System of Instruction (PSI) (e.g., [47], [55]). One of the current problems is how to develop an educational process to deal with dynamical cognitive systems whose behaviour is no longer deterministic or stochastic, but evolutionary (e.g., [46], [45]).

This paper describes our new effort to expand the BoK concept to practicing professionals, including engineers, engineering technologists, engineering technicians, managers, business developers, and innovators. The new 
concept is called the Body of Knowledge for Practitioners (BoK4P), and was developed to cope with several fundamental problems, including (i) The exploding body of science and engineering knowledge cannot be accommodated within the context of the four-year baccalaureate degree, and continuing education becomes a critical and necessary element in our professional life; (ii) Canada and many other countries now require continuing education to maintain a license to practice engineering. It is not obvious how to develop the new form of a BoK. For example, what activities would be useful either directly or indirectly to practicing professionals (practitioners) in their careers, while supporting the profession as a hole?

The BoK4P could be structured like any other existing BoK, but could also include additional elements such as best practices; failure case studies; design case studies; design files; data bases; reliability data; technical and other eBooks; prominent technical reports; simulators; emulators; and design automation tools. Although directed to practitioners primarily, this e-learning library for continuing professional development could also be applicable to all other academics, researchers, R\&D inventors, and students, thus providing feedback from practice to theory.

The development of such BoK4P documents should be facilitated by the (i) professional-practice organizations in each country such as the Association of Professional Engineers and Geoscientists of the Province of Manitoba (APEGM), (ii) professional organizations such as the Institute of Electrical and Electronics Engineers (IEEE) and the Association of Computing Machinery (ACM), (iii) educational institutions, and (iv) the professionals themselves. The printed BoK model must also be expanded to include other channels. For example, IEEE has just introduced a new professional productivity and collaboration set of tools based on social media, called Collabratec [35]. Its intent is to support both the existing IEEE communities and ad-hoc ones, as well as to support collaborative research and authoring and an opportunity to reinvent publications with supplements, discussions, and commentaries. In this expanded model, practitioners could also become knowledge creators and educators. The BOK4P may also benefit from the new interest in the open educational resources (OERs) that includes the massive open online courses (MOOCs) (e.g., [61]). Both developments are described later in this paper.

\section{Morphing of a Professional AND ITS COMPLETENESS}

\subsection{Evolution of a Professional in a Discipline}

The evolution of a person from a student to a practising professional in a specific discipline is illustrated in Fig.1. A discipline requires (i) a well-defined collection of knowledge to practice the profession, (ii) a code of ethics, and (iii) an association to enforce legal obligations of the practicing professional [36]. For example, Civil Engineering and Electrical Engineering are well-established disciplines [49], while many others are still evolving. The main nodes in this model include (i) professional education evaluated by a $\mathrm{n}$ independent body, (ii) further skill development through co-op and internship programs, as administered by the educational institutions and monitored by a professional association, (iii) licensure and certification administered and renewed by the professional association, and (iv) professional practice in industry and business, as monitored by the corresponding professional association.

Professional societies may also be involved in any stage of the process.

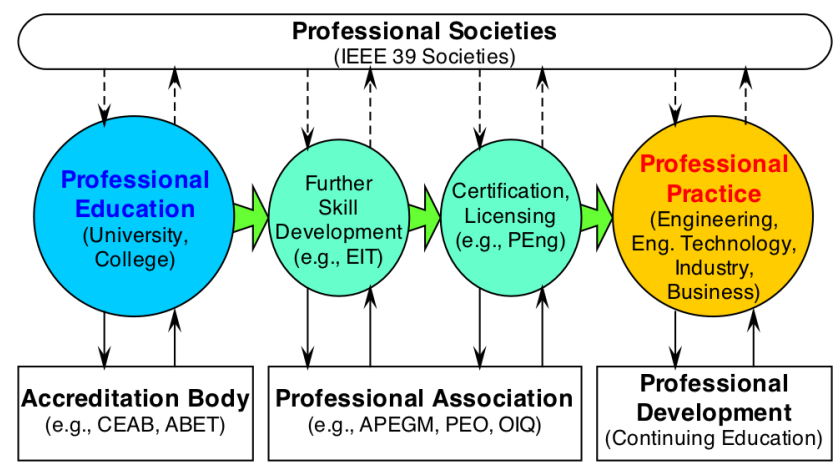

Fig. 1 Evolution of a professional in a discipline.

\section{Professional Education and Its Accreditation}

Professional schools must craft their educational programs so that the programs could be accredited by an independent body. Up to the mid-1990s, the engineering and technology programs at universities and colleges were defined and evaluated by the corresponding accreditation bodies in their home countries. For example, the Canadian Engineering Accreditation Board (CEAB) of Engineers Canada has been accrediting engineering schools in Canada [15]. In the United States, the engineering and technology programs at universities and colleges were defined by the Accreditation Board of Engineering and Technology (ABET) since 1932 [1]. In the United Kingdom, the Engineering Council UK is responsible for accreditation, and requires that their graduates meet the requisite benchmark standard for a discipline.

Over the last two decades, the newer programs have been relying much more on the body of knowledge (BoK) definition of the disciplines. The new accreditation criteria have also been upgraded to specify outcomes and attributes of a student with respect to their knowledge, skills, and attitudes. Before graduation, all the engineering students are now required to be involved in a group design final capstone project. In addition, many students are placed into internship or co-op with companies developing 
products. Preparing for an accreditation visit is a very complex and laborious process.

\section{Professional Mobility}

The educational programs must also be compatible with other countries in order to allow for mobility of the professionals. Several international agreements were signed to help recognize graduates from other countries through documents such as the Washington Accord [65], the Sydney Accord [58], the Dublin Accord [24], the International Professional Engineers Agreement [40], [30], Asia Pacific Economic Cooperation Engineer Agreement [5], and the International Engineering Technologist Agreement [39].

\section{Further Skill Development}

After graduation, engineering graduates are required to work for several years under the supervision of a licensed engineer (as Engineers-In-Training, EITs, or other titles), and are evaluated by their local professional organization such as the Association of Professional Engineers and Geoscientists of the Province of Manitoba (APEGM). The evaluation is systematic, with required input from the supervisor and other sources.

\section{Certification and Licensing}

A certification process of a professional ascertains that the individual has the expected competencies, as defined by the accreditation bodies and the appropriate BoKs. Licensing extends the certification to include active oversight of the profession, including disciplinary actions in many malpractice situations. Licensing also requires special examinations that must be passed by the candidates. Furthermore, for internationally-educated engineers, various organizations have been instituted to transfer the engineer's credentials to the new country of residence (e.g., [38]).

\section{Professional Practice}

A licensed professional is deemed qualified to practice engineering independently by providing service to the public and the profession. An engineer who is not licensed cannot practise engineering in Canada legally. Most professional associations now require that each practising professional reports on their professional development (e.g., continuing education and training) to satisfy specific requirements (i.e., specific activities and a specific number of professional-development hours). This is required because the expanding areas of knowledge do not allow all the material to be fitted into a four-year baccalaureate degree, and continuing professional development must be part of our lives.

\section{Professional Societies}

A professional society may also play an important role in the professional development through their in-person and online courses, tutorials, workshops, and seminars. For example, the Institute of Electrical and Electronics Engineers (IEEE established in 1884) has 39 societies, covering most of the engineering disciplines. The Association of Computing Machinery (ACM established in 1947) has 37 special interest groups (SIGs), also covering all the major computing disciplines. The societies may also be helpful during the academic time of a student (e.g., enhancement laboratories, workshops, networking), as well as during their postgraduate training.

\subsection{Why is This Model Incomplete?}

Figure 1 shows the traditional morphing process of an individual into a professional. Is this morphing process complete? If in doubt, look at the progression of the arrows (from left to right only). There is no feedback from the professional practitioners to the educational system.

To remedy the situation in engineering, we have started an Industrial Forum series of meetings with industry and business to discuss gaps in knowledge, skills and attitudes of our graduants [31]. The results of such discussions are evaluated critically, and fed back to the programs. However, an implementation of this feedback is done by the educators themselves.

Another attempt has been made to remedy the incompleteness by hiring practising engineers into the educational programs to provide input on design issues and help in the capstone projects. Such engineers-in-residence (EIR) have been very helpful, but they no longer practise in industry.

In contrast, medicine has a more complete feedback because many of its educators are practising physicians. Although we see this medical model as more attractive, it may not be implementable in engineering. Consequently, the BoK4P should be made a vehicle to provide the required feedback to the educational systems.

\section{EXAMPLES OF BoKS}

This section provides a list of 32 existing bodies of knowledge (BoKs). They have been selected based on (i) applicability to engineering and engineering technology, as well as related businesses, (ii) the amount of effort and cost to complete them, and (iii) potential to establish a pattern of a BoK structure for its expandability to the proposed BoK4P concept. The majority (22) of the selected documents is related to engineering, technology and computer science, while the remaining are related to management and business. The limited space in this paper gives us room to provide only major highlights and a few references for each BoK. An expanded version of the paper is also available [42], [43].

The list of BoKs is arranged alphabetically, and not according to disciplines, area, or completeness of the coverage. Each BoK also shows the major edition(s) of the 
BoK document to see that most of them have been developed over the last decade. Their upgrading is a part of the process to reflect new developments in the disciplines and new views on their relative importance.

\subsection{AMP-BoK: Association for Project Management BoK}

(Editions: 1992, 2012 6th ed.)

The Association for Project Management (APM) developed this collection of knowledge related to the professions of project, program and portfolio management. It contains 69 topics arranged in four sections [3], [4].

\subsection{BA-BoK: Business Analysis BoK}

(October 2005 v1.4; June 2006 v1.6; March 2009 v2; April 2015, v3)

The International Institute of Business Analysis (IIBA) developed this guide to the business analysis knowledge including areas of knowledge, best practices, business intelligence, information technology, business architecture and business process management [9].

\subsection{C-BoK: Common Body of Knowledge}

(1992, 1994, 2001, 2005, 2008, 2015, 4th ed.)

This is a collection of topics relevant to information security professionals, and is used to issue certification by the Certified Information Systems Security Professional (CISSP) [13].

\subsection{CC-BoK: Computing Curricula BoK}

(2004, 2005)

This document covers undergraduate degree programs in Computer Engineering, Computer Science, Information Systems, Information Technology, and Software Engineering [14], [37].

\subsection{CE-BoK: Civil Engineering BoK}

(2004, 2008)

The American Society of Civil Engineers (ASCE) is one of the oldest engineering organizations since 1852, and developed their first code of ethics in 1914. They have developed their first CE-BoK in 2005, and updated it in 2008 [7], [16]. A supplementary book was also published to address the nontechnical outcomes not covered in the CEBoK explicitly, including humanities, social sciences, experimentation, sustainability, contemporary issues, risk and uncertainty, communication, public policy, globalization, leadership and teamwork, as well as professional and ethical perspectives [49].

Following the first edition of the CE-BoK in 2005, ASCE published two influential books on the vision of a civil engineer in 2025 [6], [8].

\subsection{CIT-BoK: Canadian Information Technology BoK (2005)}

CEEA 2015; Paper 172

McMaster University; May 31-June 3, 2015
Developed by the Canadian Information Processing Society, this BoK is an outline of the knowledge bases that form the intellectual basis for the IT profession, including architecture, networks, databases, object-oriented (OO) programming, project management, service management, software, systems design, the Internet and the WWW [17].

\subsection{CM-BoK: Change Management BoK}

(2013)

The Change Management Institute (CMI) and APMGInternational (APMG) developed this document by drawing on the experience of more than six hundred change management professionals in thirty countries. It describes what change managers must know in order to display those competencies effectively, and to deliver change successfully [18].

\subsection{CMT-BoK: Chartered Market Technician BoK}

(2015)

Developed by the Market Technicians Association (MTA), this is an example of a practitioner's BoK designed to help prepare for an exam. It includes the CMT knowledge domain (theory and history; markets and market indicators; construction; trend analysis; chart and pattern analysis; selection; system testing and money management; and ethics) and CMT task domain (data collection; data analysis; decision making; and implementation) [19].

\subsection{CpE-BoK: Computer Engineering BoK}

(2004)

Developed by the Joint Task Force of the IEEE Computer Society and the Association for Computing Machinery, this BoK describes curriculum guidelines for undergraduate degree programs in computer engineering [37]. It has been very important in our enhancement of the Computer Engineering program at the University of Manitoba.

\subsection{CpET-BoK: A Computer Engineering Technology BoK}

(2010)

This is a proposal for a Computer Engineering Technology BoK, with specific topics listed and evaluated [29].

\subsection{CQE-BoK: Certified Quality Engineering BoK (2009)}

Developed by the American Society for Quality, a set of documents has been prepared to help in quality certification [20], [33].

\subsection{CS-BoK: Computer Science BoK}

(2001, 2008, 2013)

Developed by the American Society for Quality and the IEEE Computer Society, the CS-BoK is organized into a set of 18 knowledge areas (KAs), corresponding to 
topical areas of study in computing, including: (1) Algorithms and Complexity; (2) Architecture and Organization; (3) Computational Science; (4) Discrete Structures; (5) Graphics and Visualization; (6) HumanComputer Interaction; (7) Information Assurance and Security; (8) Information Management; (9) Intelligent Systems; (10) Networking and Communications; (11) Operating Systems; (12) Platform-based Development; (13) Parallel and Distributed Computing; (14) Programming Languages; (15) Software Development Fundamentals; (16) Software Engineering; (17) Systems Fundamentals; and(18) Social Issues and Professional Practice [21].

\subsection{DM-BoK: Data Management BoK}

(April 2009, 2010)

This BoK was developed by DAMA International [23]. Data management is the development, execution and supervision of plans, policies, programs and practices that control, protect, deliver and enhance the value of data and information assets. Written by 120 practitioners.

\subsection{E-BoK: Engineering BoK}

(October 2013)

Prepared by the Licensure and Qualifications for Practice Committee (LQPC) of the National Society of Professional Engineers (NSPE) [25], [64], this panengineering $\mathrm{BoK}$ elaborates on and operationalizes knowledge, skills, and attitudes, with 30 capabilities, each consisting of many diverse and specific abilities. The capabilities are organized into three categories: Basic or Foundational, Technical, and Professional Practice.

\subsection{EA-BoK: Enterprise Architecture (EA) BoK}

(February 2004)

The EABoK was developed by MITRE's Center for Innovative Computing and Informatics, with substantial funding from the US government agencies [34]. It organizes and characterizes the knowledge content of the EA discipline.

\subsection{ED-BoK: Electronic Document BoK}

This BoK was developed by Xplor International (aka Xplor ${ }^{\circledR}$ and The Electronic Document Systems Association $\left.{ }^{\circledR}\right)[26]$. It describes the entire ED development cycle.

\subsection{EIT-BoK: Enterprise Information Technology BoK (2014, not fully completed yet) \\ The IEEE Computer Society is working with the Canada Association for IT Professionals, the Australian Computer Society, and the Federation for Enterprise Architecture Professional Organizations (FEAPO) to develop the EITBoK [27].}

\subsection{EnvE-BoK: Environmental Engineering BoK}

(May 2008)

This BoK was developed for a relatively new and rapidly evolving discipline by the American Academy of Environmental Engineers (AAEE), with help from the National Science Foundation (NSF) and the Association of Environmental Engineering and Science Professors (AEESP) [28].

\subsection{GIST-BoK: Geographic Information Science and Technology BoK \\ (2006) \\ This BoK was developed by the Association of} American Geographers in 2006 [22]. The BoK addresses (i) analytical methods, (ii) Conceptual foundations, (iii) Cartography and visualization, (iv) Design aspects, and (v) Data modelling.

\subsection{IS-BoK: Information Systems BoK}

(2010)

This BoK was developed by the Association for Computing Machinery (ACM) and the Association for Information Systems (AIS) to shape the development of a model curriculum in Information Systems (IS) [60].

\subsection{IT-BoK: Information Technology BoK}

(2008)

This BoK was developed by the Association for Computing Machinery (ACM) and the IEEE Computer Society to help in setting up curricula for 4-year programs in Information technology (IT) [48], [41].

\subsection{OHS-BoK: Occupational Health and Safety BoK}

(2014)

This BoK was developed to shape educational programs and accreditation for occupational health professionals [54]. It is owned by the Health and Safety Professionals Alliance (HaSPA), a legal entity of the Safety Institute of Australia (SIA).

\subsection{PM-BoK: Project Management BoK}

(1996, 2000, 2004, 2009, 2013)

This BoK was developed by the Project Management Institute (PMI) [56]. The PMBoK discusses five processes (initiating; planning; executing; monitoring and controlling; and closing) and ten knowledge areas.

\subsection{PSP-BoK: The Personal Software Process BoK (2009)}

This BoK was developed by the Software Engineering Institute and Carnegie Mellon University [57]. It is intended to aid software professionals who are interested in using proven-effective, disciplined methods to improve their personal software development process, as well as those individuals who work with or manage projects to determine the knowledge and skills that most professionals 
should possess when working in a self-directed teaming environment such the Team Software Process.

\subsection{QE-BoK: Quality Engineering BoK}

(2006, 2009)

The QE-BoK was developed by the American Society for Quality [33]. It is a sum of all information relating to or concerning quality, and contains practical and academic content and data on defining, achieving, measuring, controlling, and improving quality.

\subsection{RE-BoK: Requirements Engineering BoK}

(2009, 2014, 2015)

The need for RE-BoK is accepted by many professionals because the biggest causes for the failure of product development is requirements [52]. It gives an introduction to the subject Requirement Engineering and to present its content and structure in a form of a standard for process structures and definitions. RE is also addressed in several other BoKs, including BABok, SE-BoK, and SWEBoK.

\subsection{SE-BoK: System Engineering BoK}

(2014, 2015)

Systems engineering is a holistic, product-oriented engineering discipline whose responsibility is to create and execute an interdisciplinary process to ensure that customer and stake-holder needs are satisfied in a high quality, trustworthy, cost-efficient and schedule-compliant manner throughout a system's life cycle [2]. This process consists of the following seven tasks: State the problem, Investigate alternatives, Model the system, Integrate, Launch the system, Assess performance, and Re-evaluate.

\subsection{SRM-BoK: Security Risk Management BoK \\ (2011)}

This BoK was developed to align with the International Standards for Risk Management (e.g., ISO 31000) and to enable professionals to apply security risk management (SRM) principles to specific areas of practice [59]. It details the security risk management process by integrating knowledge, competencies, methodologies, and applications, and it demonstrates how to document and incorporate bestpractice concepts from a range of complementary disciplines.

\subsection{SWE-BoK: Software Engineering BoK}

(2004, 2014)

This BoK was developed by the IEEE Computer Society, and constitutes a major contribution to the profession. SWEBOK is an all-inclusive term that describes the sum of knowledge within the profession of software engineering. It contains 15 knowledge areas [10].

\subsection{U-BoK: Usability Body of Knowledge} $(2010,2015)$
This BoK was developed by the Usability Professionals' Association (UPA) and the User Experience Professionals' Association (UXPA) [62]. Usability is the degree to which something (software, hardware or anything else) is easy to use and a good fit for the people who use it. It is a quality or characteristic of a product. It is whether a product is efficient, effective, and satisfying for those who use it. It is the name for a group of techniques developed by usability professionals to help create usable products.

\subsection{WE-BoK: Wireless Engineering BoK}

$(2009,2012)$

This BoK was developed by the IEEE Communications Society and published with Wiley [32]. Written by a group of international experts, the book offers a breadth of coverage and a unique focus on real-world engineering issues.

\subsection{XBPDB-IK, Best Practices Database of Indigenous Knowledge}

(2002)

This document was developed by the Dutch Nuffic and UNESCO/MOST. Indigenous knowledge (IK) is the knowledge that people in a given community have developed over time, and is based on experience, often tested over centuries of use, adapted to local culture and environment, dynamic and changing. Best practices refer to examples and cases that illustrate the good use of IK in developing cost-effective and sustainable survival strategies for poverty alleviation and income generation [11].

\section{EXTENSION OF THE BOK CONCEPT}

\subsection{A Newer Model of Education}

In the past, accreditation bodies stressed technical competence mostly. In the financial uncertainty and rapidly changing global economy, the new engineering graduate should be not only technically competent, but also be broadly knowledgeable, adaptable, and nimble, with skills such as leadership, innovation, entrepreneurship, and managing change. Continuing education is also required to maintain a license to practice engineering in many parts of the world.

The need for a body of knowledge (BoK) was articulated by many organizations, including the American Society of Civil Engineers (ASCE) in 1995, when it became clear that the previous educational model was inadequate, in that engineering education should include communication, social science, business, and economics, in addition to the technical knowledge. This position was reiterated in 2004 by the National Academy of Engineering (NAE) who published The Engineer in 2020 [51]. Two other documents have also been published by ASCE: The 
Vision for Civil Engineering in 2025 [6] and Achieving the Vision for Civil Engineering in 2025 [8].

The proposed body of knowledge for practitioners further extends the model of education by providing feedback from the practitioner to the students and educators, and by making the best practitioners knowledge creators and educators.

\subsection{Body of Knowledge for Practitioners}

\section{The Concept}

We propose a more complete model to advance the profession through mutual education and robust exchange of ideas. We should develop new tools such as Body of Knowledge for Practitioners (BoK4P) (including engineers, engineering technologists, engineering technicians, managers, business developers, innovators, and others). Possible repositories related to BoK4P could include: all existing BoK units; best practices; failure case studies; design case studies; design files; data bases; reliability data; technical IEEE and other eBooks; prominent technical reports; simulators; emulators; design automation tools. The work on the BoK4P involves a number of IEEE representatives, and started in February 2014.

The creation and distribution of BoK4P will require appropriate existing or new channels (e.g., Collabratec [35] and the open educational resources (e.g., [61]).

\section{Collabratec}

The telepresence facility, Collabratec, has recently been developed by IEEE as a professional productivity and collaboration set of tools based on social media [35]. Its intent is to support both the existing IEEE communities and ad-hoc ones, as well as to support collaborative research and authoring and an opportunity to reinvent publications with supplements, discussions, and commentaries.

\section{Open Educational Resources (OER)}

The BOK4P may also benefit from the new interest in the open educational resources (OERs) (e.g., [61]). The OERs include teaching, learning and research materials in any medium (digital and otherwise) that reside in the public domain or have been released under an open licence that permits no-cost access, use, adaptation and redistribution by others with no or limited restrictions [63].

The OER concept has been evolving since the Massachusetts Institute of Technology (MIT) started distributing educational resources online under the name OpenCourseWare (OCW) in 2001 [50]. The formation of the OCW Consortium in 2007 (now Open Education Consortium, OEC) attracted over 300 institutions who produce, reuse and remix education materials in several areas, including science and technology [53]. The Cape Town Open Education Declaration [12] has contributed further to the awareness of open access, open education, and OER. The development of the massive open online courses (MOOCs) also contributes to the expansion of the pool of material. The initial fear about the diminishing role of universities and colleges due to the OER is probably unfounded, as the knowledge creators attract new talented students to their doors.

The key idea behind OER is the ability to adapt and reuse existing pieces of knowledge. An important requirement is interoperability between various collections of open material, using effective metadata. This leads to discoverability of what already exists, and its reuse under good open licences (to retain, reuse, revise, remix, and redistribute - the 5R framework), and also under open policies (to integrate the material into the higher-education institutions).

However, all the current OER initiatives focus primarily on instructors and their undergraduate students in order to prepare them for their learned professional life. The BoK4P concept could expand the new OER initiatives to include the professional practitioners.

\section{Concluding Remarks}

This paper proposes an extension of the concept of the body of knowledge (BoK) from the traditional form serving mostly the educational institutions to a form that could serve the practitioners better, while providing a stronger feedback to the educational communities. In this model, the practitioner becomes a knowledge creator and a potential educator, not only the recipient of knowledge. In this model, design engineering is taught not only by theoreticians, but also by practitioners in the deepest sense. Another possible outcome of the proposal is that large professional organizations of tomorrow (e.g., IEEE, ACM) not only provide membership benefits, but also offer a unifying force and support for the engineering profession, with a clear collective societal and humanitarian role [44].

\section{Acknowledgements}

We would like to thank the Department of Electrical and Computer Engineering at the University of Manitoba for partial financial support of this project. I would like to thank many individuals with whom I discussed the need of expanding the role of large professional organizations such as the IEEE from providing not only membership benefits, but also offering a unifying force and support for the engineering profession, with clear collective societal and humanitarian missions. More specifically, I would like to thank Directors-Elect Bob Parro (R4), Jim Conrad (R3), Francis Grosz (R5), and Tom Coughlin (R6) for being involved in this project directly from the beginning. Additional Collabratec-related input was obtained from Fred Mintzer and Gianluca Setti, both from the IEEE Board 
of Directors, as well as from John Day, IEEE Director, Members Products and Programs.

\section{References}

[1] ABET, The Accreditation Board of Engineering and Technology. 2015. Accessed Apr 2015 from ABET at http://www.abet.org/

http://www.abet.org/accreditation/accreditationcriteria/

[2] Richard D. Adcock (EIC), Guide to the Systems Engineering Body of Knowledge (SEBoK). Hoboken, NJ: The Trustees of the Stevens Institute of Technology (SIT), April 14, 2015 (v1.3.2), 976 pp. \{Free\}. Accessed Apr 2015 from SIT at http://www.sebokwiki.org/w/downloads/SEBoKv1.3 f ull.pdf http://www.sebokwiki.org/wiki/Guide to the Systems

Engineering Body of Knowledge \%28SEBoK\%29 http://www.medicinfotech.com/wpcontent/uploads/2011/vol-5-issue-1.pdf

[3] APM-BoK, AMP Body of Knowledge. Buckinghamshire, UK: Association for Project Management, 2012, 258 pp. \{ISBN: 978-1-903494-40-0, pbk, £49.95; ISBN: 978-1-903494-41-7, hbk, £79.9; Kindle, £44.88\}. Accessed Apr 2015 from APM at http://www.apm.org.uk/BOK6 www.knowledge.apm.org.uk https://www.apm.org.uk/BoK6FurtherReading

[4] APM-BoK, APM Body of Knowledge: Definitions. Buckinghamshire, UK: Association for Project Management, 2012, 16 pp. Accessed Apr 2015 from APM at http://www.apm.org.uk/sites/default/files/FINAL \%20p roof $\% 20 \mathrm{BOK} \% 206 \% 20$ definitions.pdf

[5] APEC, Asia Pacific Economic Cooperation (APEC) Engineer Agreement. 1999. Accessed Apr 2015 from the International Engineering Alliance (IEA) at http://www.ieagreements.org/ http://www.ieagreements.org/apec/

[6] ASCE, The Vision for Civil Engineering in 2025. Reston, VA: American Society of Civil Engineers, 2007, 114 pp. \{no ISBN\}. Accessed Apr 2015 from ASCE at http://www.asce.org/uploadedFiles/About_Civil_Engin eering/Content_Pieces/vision2025.pdf http://www.asce.org/vision2025/

[7] ASCE, Civil Engineering Body of Knowledge for the 21st Century: Preparing the Civil Engineer for the Future. Reston, VA: ASCE Press, 2008 (2nd ed.), 192 pp. \{ISBN 9780784409657 pbk; \$25\}. Accessed Apr 2015 from ASCE at

http://www.asce.org/templates/publications-bookdetail.aspx?id=7987

[8] ASCE, Achieving the Vision for Civil Engineering in 2025: A Roadmap for the Profession. Reston, VA: American Society of Civil Engineers, Aug 2009, 74 pp. \{no ISBN\}. Accessed Apr 2015 from ASCE at http://www.asce.org/uploadedFiles/About Civil Engin eering/Content Pieces/vision2025-roadmap.pdf http://www.asce.org/vision2025/

[9] BA-BoK, A Guide to the Business Analysis Body of Knowledge. 31 March 2009 (v2), 272 pp. $\{\$ 59.95\}$. Accessed Apr 2015 from IIBA at http://en.wikipedia.org/wiki/Business Analysis Body of Knowledge

http://en.wikipedia.org/wiki/International Institute of Business Analysis

http://www.iiba.org/BABOK-Guide.aspx

http://www.iiba.org/babok-guide/babok-guideonline.aspx

http://www.mindmeister.com/410136309/babok-2guide-study-guide-mind-map

http://www.iiba.org/

[10] Pierre Bourque and Richard E. (Dick) Fairley (eds.), SWEBOK v3.0: Guide to the Software Engineering Body of Knowledge. Los Alamitos, CA: IEEE Computer Society Press, 2005 (v2) and 2014 (v3), 335 pp. \{ISBN: $9780769551661 ; \$ 65.00\}$. Accessed Jan 2015 from IEEE at http://www.computer.org/web/swebok/v3 http://www.computer.org/portal/web/swebok/swebokv $\underline{3}$

[11] Karin Boven and Jun Morohashi (eds.), Best Practices on Indigenous Knowledge $(X-B P D B-I K)$. The Hague, The Netherlands: Joint Publication of the Management of Social transformations Programme (MOST) and the Centre for International Research and Advisory

Networks (CIRAN), 2002, 281 pp. Accessed Jan 2015 from UNESCO at

http://www.unesco.org/most/Bpikpub2.pdf

http://www.unesco.org/most/bpindi.htm http://www.unesco.org/new/en/social-and-humansciences/themes/most-programme/

http://root.ew.eea.europa.eu/sd-online/networks/centreinternational-research-and-advisory

[12] Cape Town, Cape Town Open Education Declaration: Unlocking the promise of open education resources. 2007. Accessed Jan 2015 from Cape Town at http://www.capetowndeclaration.org/read-thedeclaration 
[13] C-BoK, Official (ISC)2 Guide to the CISSP CBK. Clearwater, FL: (ISC) ${ }^{2}$ Press, Mar 11, 2015 (4th ed.) . Accessed Jan 2015 from ISC2 at http://en.wikipedia.org/wiki/Certified_Information_Sys tems_Security_Professional http://en.wikipedia.org/wiki/Information security https://www.isc2.org/aboutus/default.aspx

[14] CC-BoK, Computing Curricula 2005: Curriculum Guidelines for Undergraduate Degree Programs in Computer Engineering, Computer Science, Information Systems, Information Technology, and Software Engineering. The Association for Computing Machinery (ACM), The Association for Information Systems (AIS), and The Computer Society (IEEE-CS), 30 Sep 2005, 62 pp. \{ISBN: 1-59593-359-X; free\}. Accessed Jan 2015 from ACM at http://www.acm.org/education/curric vols/CC2005March06Final.pdf http://www.acm.org/education/curric vols/CC2005March06Final.pdf/view

[15] CEAB, Canadian Engineering Accreditation Board. 2015. Accessed Jan 2015 from Engineers Canada at https://www.engineerscanada.ca/ https://www.engineerscanada.ca/committee-listings https://www.engineerscanada.ca/canadian-engineeringaccreditation-board

[16] CE-BoK, Civil Engineering Body of Knowledge for the 21st century: Preparing the Civil Engineer for the Future. Reston, VA: American Society of Civil Engineers, 2008 (2nd ed.), 227 pp. \{ISBN 978-0-78440965-7; Free $\}$. Accessed Jan 2015 from ASCE at http://ascelibrary.org/action/doSearch?AllField=Civil+ Engineering + Body + of + Knowledge

[17] CIT-BoK, Canadian Information Technology Body of Knowledge. Mississauga, ON: Canadian Information Processing Society, 2005, 20 pp. Accessed Jan 2015 from CIPS at http://www.cips.ca/?q=system/files/bok.pdf

[18] CM-BoK, The Effective Change Manager: Change Management Body of Knowledge. Fremantle, Western Australia: Vivid Publishing / Change Management Institute, 2013, 190 pp. \{ISBN-13: 978-1925171020; ISBN 978-0-9923624-0-9, hbk, £57.00 GBP\}. Accessed Jan 2015 from Vivid at https://www.change-managementinstitute.com/sites/default/files/CMBoK_Sample.pdf https://www.change-management-institute.com/ https://www.change-managementinstitute.com/buycmbok
[19] CMT-BoK, Chartered Market Technician (CMT) Body of Knowledge. The Market Technicians Association (MTA), 2015, $(5+4+3=) 12$ pp. Accessed Jan 2015 from CMT at

http://www.mta.org/eweb/dynamicpage.aspx?webcode =body-of-knowledge

[20] CQE-BoK, ASQ Certification Handbook. Milwaukee, WI: American Society for Quality, 2011, 21 pp.

Accessed Jan 2015 from QSO at

http://asq.org/cert/resource/pdf/certification/certificatio n-handbook.pdf

[21] CS-BoK, Computer Science Curricula 2013: Curriculum Guidelines for Undergraduate Degree Programs in Computer Science. The Joint Task Force on Computing Curricula Association for Computing Machinery (ACM) IEEE Computer Society, December 20, 2013, 518 pp. \{ISBN: 978-1-4503-2309-3\}.

Accessed Jan 2015 from ACM at http://www.acm.org/education/CS2013-final-report.pdf http://dl.acm.org/citation.cfm?id=2534860

[22] David DiBiase, Michael DeMers, Ann Johnson, Karen Kemp, Ann Taylor Luck, Brandon Plewe, and Elizabeth Wentz (eds.), Geographic Information Science and Technology Body of Knowledge (GISTBoK). Washington, DC: Association of American Geographers, 2006, 174 pp. \{ISBN-13: 9780-89291-267-4, free $\}$. Accessed Jan 2015 from AAG at http://www.aag.org/bok http://www.aag.org/galleries/publicationsfiles/GIST Body of knowledge.pdf http://ucgis.org/project-group/gist-body-knowledge2015-project

https://usccollege.qualtrics.com/SE/?SID=SV d54UV UkRgHQ7L1j

https://usccollege.qualtrics.com/SE/?SID=SV 5ik3dr4 hR5j4FdX

[23] DM-BoK, The DAMA Guide to the Data Management Body of Knowledge. Bradley Beach, NJ: Technics Publications, LLC, 2010, 430 pp. \{ISBN 9781935504023; \$74.95\}. Accessed Jan 2015 from DAMA at http://www.dama.org/content/body-knowledge http://www.technicspub.com/ http://en.wikipedia.org/wiki/Data_management http://www.dama.org/content/body-knowledge http://www.amazon.com/DAMA-Guide-ManagementKnowledge-DAMADMBOK/dp/0977140083/ref=tmm_other_meta_bindin g_swatch_0?_encoding $=$ UTF $8 \&$ sr $=$ \&qid $=$ 
[24] Dublin IEA, Dublin Accord. May 2002. Available Apr 2015 from the International Engineering Alliance (IEA) at

http://www.ieagreements.org/Dublin/

[25] E-BoK, Engineering Body of Knowledge. National Society of Professional Engineers: Prepared by the Licensure and Qualifications for Practice Committee of the National Society of Professional Engineers. 2013, 60 pp. \{Free $\}$. Accessed Jan 2015 from NSPE at http://www.nspe.org/sites/default/files/resources/nspebody-of-knowledge.pdf http://www.nspe.org/resources/education/webseminars

[26] ED-BoK, A Guide to the Electronic Document Body of Knowledge (EDBOK ${ }^{\mathrm{TM}}$ Guide). Aurora, CO: McGrewGroup LLC / MC2 Books, 2014, \{ISBN: 9781-893347-05-2, $\}$. Accessed Jan 2015 from XPLOR at http://www.edbok.org/WebSite1/EDBOK\%20LE\%20F inal $\% 20$ front $\% 20$ matter.pdf http://www.xplor.org/

[27] EIT-BoK, Enterprise Information Technology Body of Knowledge. IEEE Computer Society. 2014 (ongoing). Accessed Mar 2015 from IEEE at http://www.computer.org/web/education/eitbok

[28] EnvE-BoK, Environmental Engineering Body of Knowledge, EnvEBoK. Annapolis, MD: American Academy of Environmental Engineers, Inc. (AAEE), The Environmental Engineering Body of Knowledge Task Force, May 2009, 82 pp. \{Free\}. Accessed Mar 2015 from AAEE at

https://netforum.avectra.com/eweb/shopping/shopping. asp $x$ ? site $=$ aaees $\&$ webcode $=$ shopping $\&$ cart $=0 \&$ shopse arch $=$ body + of + knowledge https://netforum.avectra.com/eweb/DynamicPage.aspx ?WebCode $=$ HomePage $\&$ Site $=$ AAEES

[29] Jeffrey J. Evans and Douglas W. Jacobson, “A Computer Engineering Technology body of knowledge," in Proc. 40th ASEE/IEEE Frontiers in Education Conference (Washington, DC; Oct 27-30, 2010) Paper T3E, 2010.

[30] FEANI, Fédèration Européene d'Associations Nationales d'Ingénieurs / European Federation of National Engineering Associations. 2005. .Accessed Mar 2015 from FEANI at http://www.feani.org

[31] Ken Ferens, Jill Seniuk-Cicek, Nariman Sepehri, Witold Kinsner, Jean-Paul Burak, Danny Mann, Ann Parker, Dean McNeill, Doug Ruth, Ian Jeffrey, Norma Godavari, "Industry Forum III: Towards a common language," in Proc. 5th Conference of the Canadian Engineering Education Association, CEEA 2014 (Canmore, AB; June 8-11, 2014). Paper 035, 7 pp. 2014.

[32] G. Giannattasio, J. Erfanian, P. Wills, Hung Q. Nguyen, T. Croda, K. Rauscher, X. Fernando, N. Pavlidou, K. Daniel Wong (eds.), A Guide to the Wireless Engineering Body of Knowledge, WEBoK. New Wiley-IEEE Press, 2009, 272 pp. \{ISBN: 978-11183-4357-9; \$74.95 pbk; ISBN: 978-0-470-4336-9, 2009 (1st ed.), 272 pp., US\$69.95\}. Accessed Mar 2015 from IEEE at http://ieeexplore.ieee.org/xpl/bkabstractplus.jsp?bkn=6 354027

http://www.amazon.ca/Guide-Wireless-EngineeringKnowledge-WEBOK/dp/1118343573

http://www.ieee-wcet.org/resources.html

[33] Stephen Hacker, James F. Buckman, Kenneth E. Case, Michael J. Dreikorn, Deborah L. Hopen, Elizabeth M. Keim, Robert King, Gregory H. Watson, and A.H. (Jack) West, Guide to the Quality Body of Knowledge (Q-BOK). ASQ, 2009, 40 pp. Accessed Mar 2015 from ASQ at

http://asq.org/2009/04/guide-to-the-QBOK.pdf

[34] Paula J. Hagan, Guide to the (Evolving) Enterprise Architecture Body of Knowledge (EABoK). McLean, VA: The MITRE Corporation, 6 Feb 2004, 141 pp. \{free\}. Accessed Mar 2015 from MITRE at http://www.mitre.org/publications/technicalpapers/guide-to-the-evolving-enterprise-architecturebody-of-knowledge

http://en.wikipedia.org/wiki/Enterprise Architecture B ody of Knowledge

[35] IEEE, Collabratec. 2015. Accessed Mar 2015 from IEEE at https://ieee-collabratec.ieee.org/

[36] IEEE, Towards a Definition of the IT Profession. White Paper. IEEE Computer Society, Professional Activities Board, Information Technology Committee, May 16, 2010, 28 pp. Accessed Mar 2015 from IEEE at

http://www.computer.org/cms/professionaleducation/pdf/IT\%20White\%20Paper\%20\%20rev0.pdf

[37] IEEE and ACM, Computer Engineering 2004 Curriculum Guidelines for Undergraduate Degree Programs in Computer Engineering. The Joint Task Force on Computing Curricula IEEE Computer Society Association for Computing Machinery, 2004 
December 12, 160 pp. Accessed Jan 2015 from ACM at

http://www.acm.org/education/education/curric_vols/C E-Final-Report.pdf

[38] University of Manitoba, Internationally -Educated Engineers Qualification (IEEQ) Program. 2015. Accessed Mar 2015 from UofM at http://umanitoba.ca/faculties/engineering/programs/iee q/

[39] IETA, International Engineering Technologist Agreement. 25 June 2001. Accessed Mar 2015 from IEA at http://www.ieagreements.org/etmf/

[40] IPEA, International Professional Engineers Agreement. 2001. Accessed Mar 2015 from IEA at http://www.ieagreements.org/EMF/

[41] IT-BoK, Towards a Definition of the IT Profession. White Paper. IEEE Computer Society, Professional Activities Board, Information Technology Committee, May 16, 2010, 28 pp. \{Free\}. Accessed Mar 2015 from IEEE at http://www.computer.org/cms/professionaleducation/pdf/IT\%20White\%20Paper\%20\%20rev0.pdf

[42] Witold Kinsner, "Expanding the Concept of Body of Knowledge for Practitioners (BoK4P)," Report. (Winnipeg, MB: IEEE Winnipeg Section AGM; Jan 28, 2015), 2015.

[43] Witold Kinsner, "IEEE for both knowledge dicoverers and professional practitioners: The body of knowledge for practitioners (BoK4P) project," Keynote Talk. (Winnipeg, MB: IEEE Winnipeg Section AGM; Jan 28, 2015), 2015, 16 pp.

[44] Witold Kinsner, "Humanitarian engineering education: Examples," in Proc. 5th Conference of the Canadian Engineering Education Association, CEEA 2014 (Canmore, AB; June 8-11, 2014). Paper 121, 6 pp., 2014.

[45] Witold Kinsner, Simon Haykin, Yingxu Wang, Witold Pedrycz, Ivo Bukovsky, Bernard Widrow, Andrzej Skowron, Piotr Wasilewski, and Menahem Friedman, "Challenges in engineering education of cognitive dynamic systems," in Proc. of the Canadian Engineering Education Association Conference, CEEA 2012, (Winnipeg, MB, Canada; June 17-20, 2012), Paper 119, pp. 51-62, 2012. Accessed Mar 2015 from CEEA at http://library.queensu.ca/ojs/index.php/PCEEA/article/
viewFile/4633/4615

http://www.ceea.ca/images/content/ceea12-proccomplete-v35s.pdf

[46] Witold Kinsner, "Challenges in the design of adaptive, intelligent and cognitive systems," Intern. J. Software Science \& Computational Intelligence, vol. 1, no. 3, pp. 16-35, July-Sept. 2009.

[47] Witold Kinsner and Joseph J. Pear, "Computer-aided Personalized System of Instruction for the virtual classroom," Can. J. Educational Communication, vol. 17, no. 1, pp. 21-36, 1988.

[48] Barry M. Lunt, Joseph J. Ekstrom, Sandra Gorka, Gregory Hislop, Reza Kamali, Eydie Lawson, Richard LeBlanc, Jacob Miller, and Han Reichgelt, Information Technology 2008 Curriculum Guidelines for Undergraduate Degree Programs in Information Technology (IT-BoK). Association for Computing Machinery (ACM) and IEEE Computer Society, Nov 2008, 139 pp. Accessed Mar 2015 from ACM at http://www.acm.org//education/curricula/IT2008\%20C urriculum.pdf

[49] Richard H. McCuen, Edna Z. Ezzell, and Melanie K. Wong, Fundamentals of Civil Engineering: An Introduction to the ASCE Body of Knowledge. Boca Raton, FL: CRC Press, 2011, 224 pp. \{ISBN 978-14398-5148-7, pbk; \$92.09\}

[50] MIT, MIT Open Courseware. Apr 4, 2001. Accessed Apr 2015 from multiple sources at http://ocw.mit.edu/ http://ocw.mit.edu/about/our-history/ http://www.nytimes.com/2001/04/04/us/auditingclasses-at-mit-on-the-web-and-free.html

[51] National Academy of Engineering, The Engineer of 2020: Visions of Engineering in the New Century. Washington, DC: National Academies Press, 2004, 118 pp. \{ISBN 0-309-53065-2 pdf\}. Accessed Mar 2015 from NAE at

http://www.nap.edu/openbook.php?record_id=10999\& page $=1$

[52] Folke Nilsson (ed.), Requirements Engineering Body of Knowledge (RE-BoK). Global Association for Software Quality (GASQ), 2013, 51 pp.

[53] OEC, Open Education Consortium. 2007. Accessed Apr 2015 from OEC at http://www.oeconsortium.org/

[54] OHS-BoK, OHS Body of Knowledge. Tullamarine, Victoria, Australia: Safety Institute of Australia Ltd / 
Australian OHS Education Accreditation Board, 30 Oc 2014. \{ISBN 978-0-9808743-1-0; Free; Development cost: $\$ 390,000\}$. Accessed Mar 2015 from OHS at http://www.ohsbok.org.au/download-the-body-ofknowledge/

[55] Joseph J. Pear and Witold Kinsner, "Computer-Aided Personalized System of Instruction: An effective and economical method for long-distance education," Intern. J. Machine Mediated Learning, vol. 2, pp. 213237, 1988.

[56] PM-BoK, A Guide to the Project Management Body of Knowledge (PMBOK Guide). Newtown Square, PA: Project Management Institute (PMI), 2013 (5th ed.) \{ISBN 978-1-935589-67-9 5th ed; ISBN: 978-0-73816817-3 4th ed. 2011, 508 pp.; ISBN: 1-930699-45-X 3rd ed., 2004; ISBN: 1-880410-23-0, 2nd ed., 2000, 212 pp.; ISBN: ISBN: 1-880410-12-5, 1st ed., 1996, 182 pp.\}. Accessed Mar 2015 from PMI at http://ieeexplore.ieee.org/xpl/mostRecentIssue.jsp?pun umber $=6086683$

http://ieeexplore.ieee.org/Xplore/defdeny.jsp?url=http $\% 3 \mathrm{~A} \% 2 \mathrm{~F} \% 2 \mathrm{Fieeexplore.ieee.org} \% 2 \mathrm{Fstamp} \% 2 \mathrm{Fstamp}$ .jsp\%3Ftp\%3D\%26arnumber\%3D6086685\&denyReas on $=134 \&$ arnumber $=6086685 \&$ productsMatched $=$ null \&userType $=$ mem http://www.cs.bilkent.edu.tr/ cagatay/cs413/PMBOK. pdf

http://www.itq.ch/pdf/pmbok1.pdf (1996)

[57] Marsha Pomeroy-Huff, Robert Cannon, Timothy A. Chick, Julia Mullaney, and William Nichols, The Personal Software Process (PSP) Body of Knowledge (PSPBoK). Hanscom AFB, MA: Carnegie Mellon University, Software Engineering Process Management Program, 2009, v2.0, 92 pp. \{CMU/SEI2009-SR-018\}. Accessed Mar 2015 from CMU at http://www.sei.cmu.edu

[58] Sydney IEA, Sydney Accord. Jun 2001. Accessed Apr 2015 from IEA at http://www.ieagreements.org/sydney/
[59] Julian Talbot and Miles Jakeman, Security Risk Management Body of Knowledge, SRMBoK. New York, NY: Wiley, 2011, 472 pp. \{ASIN: B005OZQUGY; Kindle, \$58.04\}

[60] Heikki Topi, Joseph S. Valacich, Ryan T. Wright, Kate M. Kaiser, J.F. Nunamaker, Jr., Janice C. Sipior, and G.J. de Vreede, IS 2010 Curriculum Guidelines for Undergraduate Degree Programs in Information Systems. New York, NY: Association for Computing Machinery (ACM) and Association for Information Systems (AIS). 2010, 97 pp. Accessed Mar 2015 from $\mathrm{ACM}$ at http://www.acm.org/education/curricula/IS\%202010\% 20ACM\%20final.pdf

[61] Edmundo Tovar and Nelson Piedra, “Open educational resources in engineering education: Various perspectives opening the education of engineers," IEEE Trans. Education (Special Issue), vol. 57, no 4, pp. 213-219, Nov 2014.

[62] U-BoK, Usability Body of Knowledge (U-BoK). Accessed Apr 2015 from Usability at http://www.usabilitybok.org/

[63] UNESCO, "UNESCO promotes new initiative for free educational resources on the Internet," $2002 \mathrm{Jul} 8$. Accessed Nov 2014 from UNESCO at http://www.unesco.org/education/news en/080702 fre e edu ress.shtml

[64] Stuart G. Walesh, "NSPE's Pan-Engineering BoK," in Proc. 121th ASEE Annual Conference and Exposition (Indianapolis, IN; June 15-18, 2014), Paper ID \#9110, 2014, 30 pp. Accessed Mar 2015 from ASEE at http://www.asee.org/public/conferences/32/papers/911 0/view

[65] IEA, Washington Accord. 1989. Accessed Apr 2015 from the IEA at http://www.ieagreements.org/ http://www.ieagreements.org/WashingtonAccord/Accredited.cfm 